D) Check for updates

Cite this: Food Funct., 2017, 8, 2739

\section{Bioactivity and chemical characterization of Opuntia macrorhiza Engelm. seed oil: potential food and pharmaceutical applications}

\author{
Hassiba Chahdoura, ${ }^{a, b}$ João C. M. Barreira, (D) *b Khawla Adouni, ${ }^{a}$ Lamia Mhadhebi, ${ }^{c}$ \\ Ricardo C. Calhelha, ${ }^{b}$ Mejdi Snoussi, ${ }^{d}$ Hatem Majdoub, (iD e Guido Flamini, ${ }^{\text {f,g }}$ \\ Isabel C. F. R. Ferreira (iD *b and Lotfi Achour ${ }^{a}$
}

\begin{abstract}
In the food industry, there is a continuous search for ingredients that might provide advantageous properties to food products, either considering their nutritional value or bioactivity, as well as flavouring and technological aspects. Crude oils are good examples of this type of ingredient, especially if obtained from nonconventional sources. Accordingly, the Opuntia macrorhiza Engelm. seed oil (OMSO) was chemically characterized and evaluated for different in vitro and in vivo bioactivities. OMSO presented physicochemical characteristics appropriate to be considered as an edible oil, namely low acidity value, stability to oxidation (high peroxide value and low $K_{232}$ and $K_{270}$ values), and high contents of unsaturated fatty acids (as shown by the iodine value) and saponifiable matter. Furthermore, this natural oil, owing to its rich phytochemical profile, showed relevant antioxidant activity (especially in lipid peroxidation inhibition assays), $\alpha$-glucosidase inhibitory activity, cytotoxicity against human tumour cell lines, antibacterial (mainly against Gram positive species) and antifungal properties, as well as anti-inflammatory and analgesic activities. Furthermore, OMSO did not show any sign of acute toxicity on animals, highlighting its possible use in different applications, considering that this natural product is not expected to induce the adverse effects typically associated with synthetic bioactive agents (e.g., ampicillin, amphotericin B, or lysine acetylsalicilate).
\end{abstract}

Received 17th May 2017, Accepted 10th July 2017 DOI: $10.1039 / \mathrm{c} 7$ fo00731k rsc.li/food-function inflammatory, analgesic and antiproliferative properties, besides having the additional advantage of inducing fewer side effects. ${ }^{1}$

Different species belonging to the Opuntia genus (Cactaceae), which are native to arid and semi-arid regions, have been increasingly studied, using different botanical tissues, as high-potential sources of the previously indicated compounds. $^{2-6}$ Likewise, the biological activity of their pulps, peels or cladodes was already validated. ${ }^{7-9}$ Related research has also been directed towards Opuntia seeds, which have already proved to be a source of natural antioxidants, mainly flavonoids and tannins. ${ }^{3,5,10}$ Furthermore, the oil obtained from Opuntia spp. seeds, which usually corresponds to $7-15 \%$ of the whole seed weight, ${ }^{11}$ presents high contents of unsaturated fatty acids (especially polyunsaturated), besides being particularly rich in tocopherols (Chahdoura et al., 2015a; Simopoulos, 2002a $\mathrm{a}^{12}$ ). In addition to phenolic compounds, tocopherols might contribute to the antioxidant activity, as these compounds are capable of influencing cellular responses to various oxidative stresses by modulating signal-transduction pathways, ${ }^{13}$ besides being associated with a reduced risk of developing cardiovascular, inflammatory and autoimmune 
diseases. Other potential health benefits of Opuntia seeds, namely their anti-inflammatory activity, are associated with the presence of fatty acids of the $n-3$ and n- 6 series, such as linoleic (LA, C18:2n-6) and $\alpha$-linolenic (ALA, C18:3n-3) acids, the biosynthetic precursors of eicosanoids, which take part in a wide range of metabolic processes (Simopoulos, 2002 $\mathrm{b}^{14}$ ). However, the complete characterization of the biological activity of Opuntia species is still far from being available, particularly in what concerns specific types of bioactivity, such as $\alpha$-glucosidase inhibition or the analgesic effect.

Herein, an extensive set of laboratory assays was conducted on the O. macrorhiza seed oil (OMSO), which was characterized for different physicochemical parameters (acidity, peroxide value, extinction coefficients, saponifiable matter and iodine value), phytochemicals (carotenoids, chlorophylls, tocopherols and volatiles) and several types of bioactivity (antioxidant activity, cytotoxicity, $\alpha$-glucosidase inhibition, antimicrobial activity, analgesic effect and anti-inflammatory properties). The obtained results indicated that the otherwise discarded o. macrorhiza seeds are a potential functional food, with different applications and additional economic benefits.

\section{Experimental}

\section{Chemicals and reagents}

Racemic tocol (50 mg mL ${ }^{-1}$ ) and tocopherols $\left(\alpha-, \beta-, \gamma^{-}\right.$, and $\delta$-isoforms) were purchased from Matreya (Pleasant Gap, PA, USA). 2,2-Diphenyl-1-picrylhydrazyl (DPPH), 2,2'-azino-bis (3-ethylbenzothiazoline-6-sulphonic acid) diammonium salt (ABTS), potassium ferricyanide $\left[\mathrm{K}_{3} \mathrm{Fe}(\mathrm{CN})_{6}\right]$, ferric chloride $\left(\mathrm{FeCl}_{3}\right)$, trichloroacetic acid (TCA), $\beta$-carotene, linoleic acid, hydrochloric acid $(\mathrm{HCl})$, sodium hydroxide $(\mathrm{NaOH})$, penicillin/ streptomycin solution $\left(100 \mathrm{U} \mathrm{mL}^{-1}\right.$ and $100 \mathrm{mg} \mathrm{mL}^{-1}$, respectively), $\alpha$-glucosidase (isolated from Aspergillus Niger), and 4- $p$-nitrophenyl- $\alpha$-D-glucopyranoside (4- $p$ NPG) were purchased from Sigma-Aldrich. Mueller-Hinton agar, nutrient broth and Brain Heart Infusion broth (BHI) were purchased from Biolife (Monza, Italy). NaCl was obtained from CHEMI PHARMA, Tunisia. Hexane, chloroform and methanol were purchased from Merck (Darmstadt, Germany).

\section{Samples}

O. macrorhiza (Engelm.) fruits were manually harvested in spring (2015) from the cliff of Monastir (Tunisia) according to the conventional standards of maturation (size and skin colours). The seeds were separated from the juicy pulp, washed abundantly with distilled water, dried at room temperature for $24 \mathrm{~h}$, weighed and then reduced to a fine homogenous powder (20 mesh). The plant material was identified by Pr. Fethia Harzallah Skhiri (High Institute of Biotechnology of Monastir, Tunisia). A voucher specimen (no. Oma 15-18) has been deposited in the Herbarium of the Laboratory of Bioressources: Biologie Integrative and Valorization, High Institute of Biotechnology of Monastir.

\section{Extraction}

OMSO was extracted from a known weight ( $\approx 100 \mathrm{~g})$ of powdered seeds with hexane, using a Soxhlet apparatus $(8 \mathrm{~h})$. OMSO was then filtered through a syringe filter of $0.2 \mu \mathrm{m}$ and stored at $-20{ }^{\circ} \mathrm{C}$ in the dark, until analysis.

\section{Physicochemical analyses}

Acidity, peroxide value, extinction coefficients $\left(K_{232}\right.$ and $\left.K_{270}\right)$, saponifiable matter and iodine value were determined according to Official Methods and Recommended Practices of the American Oil Chemists' Society (AOCS, $1998^{15}$ ). The refractive index was determined by using an Abbe refractometer (model R-410A) with temperature adjustment.

\section{Phytochemicals}

Pigments. Carotenes and chlorophylls were determined in cyclohexane extracts at 470 and $670 \mathrm{~nm}$, respectively, using specific extinction values (Minguez-Mosquera et al., 1991 ${ }^{16}$ ). The results were expressed as mg of pheophytin " $\alpha$ " or lutein per kg of OMSO.

Tocopherols. Tocopherol content was chromatographically determined following a previously optimized procedure. ${ }^{5}$ Compounds were identified by chromatographic comparisons with commercial standards and quantified considering the fluorescence signal response of each standard, using the IS (tocol) method and the calibration curves obtained from each commercial standard. Results were expressed in $\mathrm{mg}$ per $100 \mathrm{~g}$ of OMSO.

Volatile compound analyses. Volatile compounds were determined by headspace solid phase micro-extraction (HS-SPME) coupled to gas chromatography/mass spectrometry (GC/MS) as previously described. ${ }^{17}$

\section{Antioxidant activity}

Five antioxidant activity assays were performed for different concentrations of OMSO, previously diluted in methanol: ABTS and DPPH radical scavenging activity, reducing power, $\beta$-carotene bleaching inhibition and thiobarbituric acid reactive substance (TBARS) formation inhibition.

In the ABTS assay, an aqueous solution of ABTS (7 mM) was initially prepared. Then, the ABTS radical cation $\left(\mathrm{ABTS}^{\circ+}\right)$ was produced from the reaction (12-16 $\mathrm{h}$ in the dark, room temperature) among the previous solution with $2.45 \mathrm{mM}$ potassium persulfate (final concentration). ${ }^{18}$ To study the radical scavenging activity of OMSO, the $\mathrm{ABTS}^{{ }^{+}}$solution was diluted with ethanol to an absorbance of $\approx 0.70$ at $734 \mathrm{~nm}$ (equilibrated at $\left.30{ }^{\circ} \mathrm{C}\right)$. The decrease $(\%)$ in absorbance at $734 \mathrm{~nm}$ achieved after mixing the ethanolic solution of $\operatorname{ABTS}^{*+}(1 \mathrm{~mL})$ and the OMSO $(10 \mu \mathrm{L})$ was calculated by comparison with Trolox reference data. $^{18}$

Four other antioxidant activity assays were performed as previously described. ${ }^{5}$ DPPH radical-scavenging activity was evaluated by using an ELX800 microplate reader (BioTek Instruments, Inc.; Winooski, VT, USA) and calculated as a percentage of DPPH discoloration using the formula: 
$\left[\left(A_{\mathrm{DPPH}}-A_{\mathrm{S}}\right) / A_{\mathrm{DPPH}}\right] \times 100$, where $A_{\mathrm{S}}$ is the absorbance of the solution containing the sample at $515 \mathrm{~nm}$, and $A_{\mathrm{DPPH}}$ is the absorbance of the DPPH solution.

Reducing power was evaluated by the capacity to convert $\mathrm{Fe}^{3+}$ into $\mathrm{Fe}^{2+}$, measuring the absorbance at $690 \mathrm{~nm}$ in the microplate reader mentioned above.

Inhibition of $\beta$-carotene bleaching was evaluated through the $\beta$-carotene/linoleate assay; the neutralization of linoleate free radicals avoids $\beta$-carotene bleaching, which is measured by the formula: ( $\beta$-carotene absorbance after $2 \mathrm{~h}$ of assay/ initial absorbance) $\times 100$.

Inhibition of lipid peroxidation in porcine (Sus scrofa) brain homogenates was evaluated by the decrease in TBARS formation; the colour intensity of the malondialdehydethiobarbituric acid (MDA-TBA) was measured at $532 \mathrm{~nm}$; the inhibition ratio (\%) was calculated using the following formula: $[(A-B) / A] \times 100 \%$, where $A$ and $B$ are the absorbances of the control and the sample solutions, respectively.

In all cases, the results were expressed as $\mathrm{EC}_{50}$ values (sample concentration providing $50 \%$ of antioxidant activity or 0.5 of absorbance in the reducing power assay) in $\mathrm{mg} \mathrm{mL}^{-1}$ of extract. Trolox was used as a positive control.

\section{Cytotoxicity}

Human tumour cell lines. Four human tumour cell lines were used: MCF-7 (breast carcinoma), NCI-H460 (non-small cell lung cancer), HeLa (cervical carcinoma) and HepG2 (hepatocellular carcinoma). Cells were maintained as adherent cultures in RPMI-1640 medium containing 10\% heat-inactivated FBS and $2 \mathrm{mM}$ glutamine, at $37{ }^{\circ} \mathrm{C}$, in a humidified air incubator containing $5 \% \mathrm{CO}_{2}$. Each cell line was plated at an appropriate density $\left(7.5 \times 10^{3}\right.$ cells per well for MCF-7 and NCI-H460 or $1.0 \times 10^{4}$ cells per well for HeLa and HepG2) in 96-well plates. The sulforhodamine B assay was performed as previously described. ${ }^{19}$ Results were expressed as $\mathrm{GI}_{50}$ values (sample concentration that inhibited $50 \%$ of the net cell growth) in $\mathrm{mg} \mathrm{mL} \mathrm{m}^{-1}$.

Non-tumour liver cell primary culture. A cell culture (PLP2) was prepared from a freshly harvested porcine liver obtained from a local slaughter house and cultured as previously described. ${ }^{19}$ Before confluence was reached, cells were subcultured and plated in 96-well plates $\left(\approx 1.0 \times 10^{4}\right.$ cells per well $)$, using DMEM with $10 \% \mathrm{FBS}, 100 \mathrm{U} \mathrm{mL}^{-1}$ penicillin and 100 $\mu \mathrm{g} \mathrm{mL} \mathrm{m}^{-1}$ streptomycin. Results were expressed as $\mathrm{GI}_{50}$ values, in $\mathrm{mg} \mathrm{mL} \mathrm{m}^{-1}$. Ellipticine was used as a positive control.

\section{$\alpha$-Glucosidase inhibition assay}

Enzyme activity was measured following a previous procedure ${ }^{20}$ with some modifications. The $\alpha$-glucosidase reaction mixture, containing $2.5 \mathrm{mM} 4$ - $p$-nitrophenyl- $\alpha$-D-glucopyranoside (4- $p \mathrm{NPG}), 250 \mu \mathrm{L}$ of OMSO at different concentrations in DMSO and $0.3 \mathrm{U} \mathrm{mL}^{-1}$ of $\alpha$-glucosidase in phosphate buffer $\mathrm{pH}$ 6.9, was incubated in a water bath $\left(37^{\circ} \mathrm{C}, 15 \mathrm{~min}\right)$. Negative control tubes contained only DMSO, enzyme and substrate, while in positive controls Acarbose replaced OMSO. The absorbance $(405 \mathrm{~nm})$ of the resulting $p$-nitrophenol $(p \mathrm{NP})$ was considered directly proportional to the enzyme activity. Percentage inhibition (I\%) of OMSO and Acarbose was calculated using the following formula:

$$
I \%=\left(A_{\text {control }}-A_{\text {sample }}\right) / A_{\text {control }} \times 100
$$

where $A_{\text {control }}$ and $A_{\text {sample }}$ are the absorbance values of the negative control and sample, respectively. Results were presented as $\mathrm{IC}_{50}\left(\mathrm{mg} \mathrm{mL}^{-1}\right)$ values (concentration of OMSO required to inhibit $50 \%$ of intestinal $\alpha$-glucosidase).

\section{Antimicrobial activity}

Microorganisms. The tested microorganisms included Gram-positive: Staphylococcus aureus ATCC 25923, Listeria monocytogenes ATCC 19115, Bacillus cereus ATCC 11778 and Enterococcus faecalis ATCC 29212 and Gram negative: Vibrio parahaemolyticus ATCC 17802, Escherichia coli ATCC 35218, Pseudomonas aeruginosa ATCC 27853 and Salmonella typhimurium ATCC 1408 bacteria and four Candida strains (C. albicans ATCC 2091, C. parapsilosis ATCC 22019, C. glabrata 06-085 and C. krusei ATCC 6258).

Disc-diffusion assay. For antimicrobial activity experiments, $10 \mu \mathrm{L}$ of the microorganism working stock solutions were enriched on a tube containing $9 \mathrm{~mL}$ of Mueller-Hinton broth (for bacteria) and Sabouraud Chloramphenicol broth (for Candida) and further incubated at $37{ }^{\circ} \mathrm{C}$ for $24 \mathrm{~h} .^{21}$ The optical density was adjusted $\left(0.1\right.$ at $\mathrm{OD}_{600}$ for bacteria and 0.4 at $\mathrm{OD}_{540}$ for Candida strains). The inocula of the respective bacteria and fungus were streaked onto agar plates using a sterile cotton swab as recommended by the CA-SFM EUCAST 2017. Sterile filter discs (diameter $6 \mathrm{~mm}$, Biolife Italy) were impregnated with $10 \mu \mathrm{L}$ of OMSO and placed on the appropriate media. Ampicillin (10 mg mL $\mathrm{m}^{-1} ; 10 \mu \mathrm{L}$ per disc) and Amphotericin B $\left(10 \mathrm{mg} \mathrm{mL} \mathrm{mL}^{-1} ; 10 \mu \mathrm{L}\right.$ per disc) were used as positive reference standards. After $24 \mathrm{~h}$ of incubation at $37^{\circ} \mathrm{C}$, the diameter of the growth inhibition zone was measured with a flat millimetric rule.

Micro-well determination of MICs and MBCs/MFCs. The minimal inhibition concentration (MIC) and the minimal bactericidal/fungicidal concentration (MBC/MFC) values were determined for all the bacterial/fungal strains. ${ }^{22}$ The bacterial/ fungal inocula, prepared from $12 \mathrm{~h}$ broth cultures and suspensions, were spectrophotometrically adjusted to $10^{7} \mathrm{UFC} \mathrm{mL}^{-1}$. OMSO was first dissolved in $10 \%$ dimethylsulfoxide (DMSO) to the highest concentration $\left(50 \mathrm{mg} \mathrm{mL}^{-1}\right.$ ), and then serial twofold dilutions were made in a concentration range from 25 to $0.048 \mathrm{mg} \mathrm{mL}^{-1}$ in $5 \mathrm{~mL}$ sterile glass tubes containing nutrient broth. 96-well plates were prepared by dispensing into each well $95 \mu \mathrm{L}$ of nutrient broth. A $100 \mu \mathrm{L}$ aliquot from the stock solutions of the tested OMSO was added into the wells, followed by $5 \mu \mathrm{L}$ of each microbial suspension. The first well containing $195 \mu \mathrm{L}$ of nutrient broth (Mueller Hinton broth or Sabouraud Chloramphenicol broth) without OMSO and $5 \mu \mathrm{L}$ of the inoculum was used as a negative control. The final volume in each well was $200 \mu \mathrm{L}$. The plates were incubated at $37^{\circ} \mathrm{C}$ for $24 \mathrm{~h}$. The MIC was defined as the lowest concen- 
tration of the compounds to inhibit the growth of the microorganisms. The MBC/MFC values were interpreted as the highest dilution (lowest concentration) of the sample, which showed a clear fluid with no development of turbidity and without visible growth. All the tests were performed in triplicate.

\section{Animal tests}

Animals were obtained from the Pasteur Institute (Tunis, Tunisia). Male adult Wistar rats weighing 160-180 g were used for the anti-inflammatory evaluation of OMSO. Also, Swiss albinos mice (weighing 18-25 g) were used for the analgesic investigation and for acute toxicity testing on both sex. They were housed in polypropylene cages and were left for 2 days for acclimatization to the animal room, maintained under controlled conditions ( $12 \mathrm{~h}$ light-dark cycles at $22 \pm 2^{\circ} \mathrm{C}$ ) on a standard pellet diet and water ad libitum. Before the day of assay, the Wistar rats and Swiss albinos mice were fasted overnight with free access to water. Animals were handled according to the guidelines of the Tunisian Society for the Care and Use of Laboratory Animals (ATSAL), and the protocol for the rat studies was approved by Institutional Animal Ethics Committee for Animal Care and Use, Bizerte University, Carthage.

Acute toxicity. Mice were divided into groups of six animals each. Five groups were used to study toxicity using a single intraperitoneal dose. Each group received, respectively, a single dose of $0.5,1,2$ and $3 \mathrm{~g}$ per $\mathrm{kg}$ body weight of OMSO or distilled water $\left(10 \mathrm{~mL} \mathrm{~kg}^{-1}\right)$. After treatment, the mortality rate within a $48 \mathrm{~h}$ period and autonomic toxic effects were determined.

Analgesic activity. Analgesic activity was assessed by the acetic acid abdominal constriction test (writhing test), a chemical visceral pain model. ${ }^{23}$ Swiss albinos mice were selected 1 day prior to each test and were divided into groups of six mice each. Negative and positive controls were dermally pre-treated with $10 \mathrm{~mL} \mathrm{~kg}{ }^{-1}$ of saline solution or $200 \mathrm{mg} \mathrm{kg}^{-1}$ of the reference drug lysine acetylsalicylate (ASL), respectively. The remaining groups were injected intraperitoneally with $10 \mathrm{~mL} \mathrm{~kg}^{-1}$ of $1 \%$ acetic acid solution $30 \mathrm{~min}$ after the administration of different doses of $0.5,1.0$ and $2.5 \mathrm{~g} \mathrm{~kg}^{-1}$ of OMSO. Afterwards, the number of writhes was counted during $30 \mathrm{~min}$. Antinociceptive activity was expressed as the inhibition percentage of the usual number of writhes observed in control animals. The percentages of inhibition were calculated according to the formula:

$$
\begin{aligned}
\% \text { Inhibition }= & \left((\text { number of writhes })_{\text {control }}\right. \\
& \left.-(\text { number of writhes })_{\text {treated group }}\right) \\
& \times 100 /(\text { number of writhes })_{\text {control }}
\end{aligned}
$$

Anti-inflammatory activity. Anti-inflammatory activity was assessed based on the inhibition of paw oedema induced by the injection of carrageenan (an oedematogenic agent) into the sub-plantar region of the right hind paw. ${ }^{24}$ Male Wistar rats were divided into different groups of 6 animals. Negative and positive controls received $2.5 \mathrm{~mL} \mathrm{~kg}^{-1}$ of saline solution or $300 \mathrm{mg} \mathrm{kg}{ }^{-1}$ of ASL, respectively. Test groups received different concentrations $\left(0.5,1.0\right.$ and $\left.2.5 \mathrm{~g} \mathrm{~kg}^{-1}\right)$ of OMSO. Thirteen minutes after intraperitoneal administration of different substances, $0.05 \mathrm{~mL}$ of a carrageen suspension (1\%) was injected to all animals in the right hind paw. The paw volume, up to tibiotarsal articulation, was measured using a plethysmometer at $0 \mathrm{~h}$ ( $V_{0}$ : before oedematogenic agent injection) and 1, 2, 3, 4, 5 and $24 \mathrm{~h}$ intervals later $\left(V_{\mathrm{T}}\right)$. The difference between $V_{\mathrm{T}}(1,2,3,4,5$ and $24 \mathrm{~h}$ ) and $V_{0}$ was taken as the oedema value. The percentages of inhibition were calculated according to the formula:

$$
\begin{aligned}
\% \text { Inhibition }= & \left(\left(V_{\mathrm{T}}-V_{0}\right)_{\text {control }}-\left(V_{\mathrm{T}}-V_{0}\right)_{\text {treated group }}\right) \\
& \times 100 /\left(V_{\mathrm{T}}-V_{0}\right)_{\text {control }}
\end{aligned}
$$

\section{Statistical analysis}

All the tests were carried out for three sample replications and the results were averaged. The means \pm standard deviation (SD) of data was calculated from independent experiments. The exact sample size $(n)$ for each experimental group is reported in the manuscript and in table captions. Data analysis was carried out using one-way ANOVA analyses followed by the Student-Newman-Keuls post hoc test. Statistical analyses were performed using GraphPad Prism and InStat softwares (GraphPad Software, La Jolla, USA). All statistical tests were two-tailed and a $p$ value $\leq 0.05$ was considered significant.

\section{Results and discussion}

\section{Physicochemical parameters}

The physicochemical parameters relevant to assess the oil quality are reported in Table 1. OMSO is liquid at room temperature and it has a yellow-brown colour and mild, yet characteristic, flavour and odour. The detected acidity was very low $(1.15 \%)$, and even lower than the one (1.41-1.82\%) reported for Opuntia ficus indica seeds' oil, ${ }^{25,26}$ fulfilling the acceptability criterion that defines a maximum acidity of $3 \%{ }^{27}$ The iodine value is high (110 $\mathrm{g}$ of $\mathrm{I}_{2}$ per $100 \mathrm{~g}$ ), reflecting the high content in unsaturated fatty acids. ${ }^{5}$ Likewise, the peroxide index was 2.8 meq per $\mathrm{O}_{2}$ per $\mathrm{kg}$ of OMSO, indicating a good stability to oxidation and suggesting, together with the iodine value, good edible quality. The peroxide index values are close to those reported for the seed oil of $O$. ficus indica. ${ }^{25,26,28}$ The resistance to oxidation is also reflected by the low extinction coefficients (0.98 and 0.015 at 232 and $270 \mathrm{~nm}$, respectively).

Table 1 Physicochemical parameters evaluated in OMSO

\begin{tabular}{ll}
\hline Parameter & Mean value $\pm \mathrm{SD}(n=3)$ \\
\hline Free acidity $(\%)$ & $1.15 \pm 0.05$ \\
Saponification value & $179 \pm 1$ \\
(mg of $\mathrm{KOH}$ per $\mathrm{g}$ of $\mathrm{oil})$ & \\
Iodine value $\left(\mathrm{g} \mathrm{I}_{2}\right.$ per $\left.100 \mathrm{~g}\right)$ & $110 \pm 1$ \\
Peroxide value $\left(\mathrm{meq}_{2}\right.$ per $\mathrm{kg}$ of oil) & $2.8 \pm 0.2$ \\
Refractive index $\left(20^{\circ}\right)$ & $1.48 \pm 0.01$ \\
Extinction coefficients & \\
$\quad K_{232}$ & $0.98 \pm 0.05$ \\
$K_{270}$ & $0.015 \pm 0.003$ \\
Physical state at room temperature & Liquid \\
Oil colour & Yellow-brown
\end{tabular}


In fact, $K_{232}$ is an indicator of the formation of hydroperoxide and conjugated dienes, while $K_{270} \mathrm{~nm}$ is associated with the secondary phase of oxidation, reflecting the presence of the final products (such as trienes or unsaturated carbonyl compounds), which contribute to the characteristic flavour of oxidized oils. ${ }^{29}$ Lastly, the saponification value was $179 \mathrm{mg}$ of $\mathrm{KOH}$ per $\mathrm{g}$ of OMSO, also in good agreement with the ones (177-181 $\mathrm{mg}$ of $\mathrm{KOH}$ per $\mathrm{g}$ ) reported for O. ficus indica oil. ${ }^{25,26}$ Nevertheless, despite the pointed out similarities with the seed oil from $O$. ficus indica, it should be highlighted that the seeds of $O$. macrorhiza provide a higher oil quantity (around $10 \mathrm{~g}$ per $100 \mathrm{~g}$ dry weight) than that achievable with O. ficus indica $\left(\approx 5 \mathrm{~g}\right.$ per $100 \mathrm{~g}$ dry weight). ${ }^{26}$ In either case, the oils obtained from Opuntia seeds are expected to be good sources of mineral elements as well, particularly phosphorous, calcium and potassium. ${ }^{30}$

\section{Phytochemicals}

Among pigment compounds (Table 2), $\beta$-carotene was the major one (41.8 $\mathrm{mg} \mathrm{kg}^{-1}$ ), opening the way for different uses, especially in the cosmetic industry. Chlorophylls were present in lower amounts $\left(3.0 \mathrm{mg} \mathrm{kg} \mathrm{kg}^{-1}\right.$ ), in agreement with typical values reported for the Opuntia genus. ${ }^{28}$ Chlorophylls and carotenoids are important to determine the oil quality, mostly due to their contribution to the oil colour, which is a relevant parameter when assessing the overall quality. ${ }^{31}$ Furthermore, carotenoids are well-known quenchers of singlet oxygen, being able to protect oils from photo-oxidation. ${ }^{32}$

Table 2 Phytochemicals quantified in OMSO

\begin{tabular}{ll}
\hline Compound & Mean value $\pm \operatorname{SD}(n=3)$ \\
\hline Tocopherols & $(\mathrm{mg}$ per $100 \mathrm{~g}$ of OMSO $)$ \\
$\alpha$-Tocopherol & $0.34 \pm 0.01$ \\
$\beta$-Tocopherol & $0.36 \pm 0.01$ \\
$\gamma$-Tocopherol & $9.8 \pm 0.1$ \\
$\delta$-Tocopherol & $0.20 \pm 0.01$ \\
Total tocopherols & $10.7 \pm 0.1$ \\
Pigments & $\left(\mathrm{mg} \mathrm{kg}^{-1}\right.$ of OMSO $)$ \\
Chlorophylls & $3.0 \pm 0.1$ \\
$\beta$-Carotene & $41.8 \pm 0.1$ \\
\hline
\end{tabular}

\begin{tabular}{lcl}
\hline Volatiles $^{a}$ & LRI $^{b}$ & $(\%)^{c}$ \\
\hline 4-Hydroxy-4-methyl-2-pentanone & 847 & $1.32 \pm 0.01$ \\
Ethyl isovalerate & 854 & $1.70 \pm 0.02$ \\
$n$-Nonane & 900 & $4.12 \pm 0.01$ \\
Ethyl valerate & 902 & $58.1 \pm 0.1$ \\
$\alpha$-Pinene & 941 & $1.04 \pm 0.01$ \\
Camphene & 955 & $1.22 \pm 0.01$ \\
$n$-Decane & 1000 & $1.13 \pm 0.03$ \\
$\beta$-Phellandrene & 1033 & $2.32 \pm 0.02$ \\
1,8-Cineole & 1035 & $3.04 \pm 0.04$ \\
(E)-2-Octenal & 1063 & $1.24 \pm 0.01$ \\
$n$-Undecane & 1100 & $2.04 \pm 0.04$ \\
Nonanal & 1102 & $1.31 \pm 0.01$ \\
Camphor & 1145 & $19.6 \pm 0.1$
\end{tabular}

${ }^{a}$ Identification was performed by the calculation of L.R.I and by MS data. ${ }^{b}$ LRI: linear retention indices (HP-5 column). ${ }^{c} \%$ : percentage calculated by GC-FID on non-polar capillary column HP-5.
Regarding tocopherol contents (Table 2), four isoforms $(\alpha, \beta, \gamma$ and $\delta$-tocopherol) were identified, with $\gamma$-tocopherol as the major component. This particular isoform was also reported as the main constituent ( $9.8 \mathrm{mg}$ per $100 \mathrm{~g}$ of oil) in the seed oil of $O$. ficus indica. ${ }^{33}$ Considering their prevention activity on the peroxidation of polyunsaturated fatty acids, tocopherols certainly contribute to OMSO stability towards oxidation, ${ }^{34}$ improving its quality by preserving it from rancidity during storage and prolonging its shelf-life. ${ }^{35}$

Additionally, the headspace of OMSO was characterized by 13 spontaneously emitted volatile compounds (Table 2). The chemical analysis revealed high contents of ethyl valerate (58.1\%), known for its floral sensory notes, and camphor (19.6\%), an oxygenated monoterpene with a typical aromatic odour. ${ }^{36}$ All the remaining volatiles were detected in percentages below 5\%. Besides their contribution to the aroma profile of OMSO, these compounds might also influence its physical and biological properties. ${ }^{37}$

\section{Antioxidant activity}

OMSO showed to be particularly active in preventing lipid peroxidation, as indicated by the results obtained in the inhibition of TBARS formation $\left(\mathrm{EC}_{50}=0.90 \mathrm{mg} \mathrm{mL} \mathrm{m}^{-1}\right)$ and $\beta$-carotene bleaching inhibition $\left(\mathrm{EC}_{50}=10 \mathrm{mg} \mathrm{mL}^{-1}\right)$.

The $\mathrm{EC}_{50}$ values for all assays (Table 3 ) are similar to those reported for the polar extracts of seeds, as also to those reported for other tissues (cladodes and flowers) of O. macrorhiza., ${ }^{5,38}$ Besides its lipid peroxidation inhibition, OMSO also has a good radical scavenging activity $\left(\mathrm{DPPH} \mathrm{EC} \mathrm{EC}_{50}=1.99 \mathrm{mg} \mathrm{mL}{ }^{-1}\right.$; $\mathrm{ABTS}^{\circ+}$ $\left.\mathrm{EC}_{50}=3.62 \mathrm{mg} \mathrm{mL} \mathrm{mL}^{-1}\right)$ and reducing power $\left(\mathrm{EC}_{50}=1.24\right.$ $\mathrm{mg} \mathrm{mL}^{-1}$ ). The detected antioxidant activity is in agreement with the low values of $K_{232}$ and $K_{270}$, and should be associated (as previously indicated) with the contents in tocopherols and carotenoids (see section Phytochemicals). In fact, it was reported that tocopherols (especially $\gamma$-tocopherol) could enhance the activity of superoxide dismutase, thereby contributing to different antioxidant effects. ${ }^{39}$

\section{Cytotoxic activity}

The cytotoxic effect of OMSO on different cell lines (HeLa, HepG2, MCF 7 and HCT15), which had not been previously reported, is shown in Table 4 . With the exception of MCF7 cells, OMSO was active against all the tested tumour cell lines, with $\mathrm{GI}_{50}$ values ranging from $105 \mu \mathrm{g} \mathrm{mL}^{-1}$, in the case of

Table 3 Antioxidant activity of OMSO (values are presented as mean values \pm SD)

\begin{tabular}{ll}
\hline Antioxidant activity & $\mathrm{EC}_{50}{ }^{a}\left(\mathrm{mg} \mathrm{mL}^{-1}\right)$ \\
\hline DPPH scavenging activity & $1.99 \pm 0.01$ \\
ABTS & $3.62 \pm 0.02$ \\
Reducing power & $1.24 \pm 0.04$ \\
$\beta$-Carotene bleaching inhibition & $1.10 \pm 0.01$ \\
TBARS inhibition & $0.90 \pm 0.02$
\end{tabular}

${ }^{a} \mathrm{EC}_{50}$ : OMSO concentration corresponding to $50 \%$ of antioxidant activity or 0.5 of absorbance in reducing power assay. 
Table 4 Cytotoxic activity of OMSO (values are presented as mean values \pm SD)

\begin{tabular}{ll}
\hline Cell lines & $\mathrm{GI}_{50}{ }^{a}\left(\mu \mathrm{g} \mathrm{mL}^{-1}\right)$ \\
\hline Human tumour cell lines & \\
MCF7 (breast carcinoma) & $>400$ \\
HCT15 (colon carcinoma) & $215 \pm 5$ \\
HeLa (cervical carcinoma) & $105 \pm 4$ \\
HepG2 (hepatocellular carcinoma) & $358 \pm 11$ \\
Non-tumour cells & $>400$ \\
$\quad$ PLP2 & \\
${ }^{a}{ }^{\text {GI }}$ (50 values correspond to the OMSO concentration achieving $50 \%$ of \\
growth inhibition.
\end{tabular}

HCT15 (colon carcinoma), to $358 \mu \mathrm{g} \mathrm{mL} \mathrm{mL}^{-1}$, for HepG2 (hepatocellular carcinoma). Therefore, HCT15 was the most susceptible cell line, while MCF7 resulted to be the most resistant one. Interestingly, OMSO showed no toxicity (up to 400 $\mu \mathrm{g} \mathrm{mL}{ }^{-1}$ ) against the non-tumour cell line PLP2.

\section{In vitro $\alpha$-glucosidase inhibition assay}

The maintenance of blood glucose levels is a very important subject, continuously required for effective approaches, such as the inhibition of $\alpha$-glucosidase, which leads to a decrease in the rate of glucose absorption, lowering its postprandial blood levels. ${ }^{40}$ Accordingly, the capacity of OMSO to inhibit $\alpha$-glucosidase was also assessed, having been obtained an $\mathrm{EC}_{50}$ value of $0.34 \mathrm{mg} \mathrm{mL} \mathrm{m}^{-1}$, which is similar to that of Acarbose $\left(\mathrm{EC}_{50}=0.26 \mathrm{mg} \mathrm{ml} \mathrm{m}^{-1}\right)$, used herein as the positive control. Therefore, OMSO might be an interesting alternative, as it is not expected to induce side effects (such as abdominal pain, flatulence and diarrhoea) that are usually associated with other blood glucose controlling agents. ${ }^{41}$

The effectiveness of OMSO in this particular type of bioactivity might be related to its high levels of tocopherols, since it has been reported that the administration of $\gamma$-tocopherol to diabetes mellitus patients exerts a blood glucose lowering effect. ${ }^{42}$

\section{Antimicrobial activity}

Data on the antimicrobial activity of OMSO, reported herein for the first time, are given as inhibition zone (IZ) diameters, MICs and MBCs/MFCs (Table 5). The antibacterial activity was substantially higher among Gram positive (IZ from 7 to $11 \mathrm{~mm}$ ) and yeast (IZ from 10.3 to $12.3 \mathrm{~mm}$ ) strains, with Listeria monocytogenes $\left(\mathrm{IZ}=11 \mathrm{~mm} ; \mathrm{MIC}=0.390 \mathrm{mg} \mathrm{mL} \mathrm{mL}^{-1}\right.$; $\left.\mathrm{MBC}=1.56 \mathrm{mg} \mathrm{mL}^{-1}\right)$ and Candida albicans $(\mathrm{IZ}=12.3 \mathrm{~mm}$; $\mathrm{MIC}=0.781 \mathrm{mg} \mathrm{mL}^{-1} ; \mathrm{MFC}=1.56 \mathrm{mg} \mathrm{mL}^{-1}$ ) as the most sensitive species. The presence of camphor (19.6\%), 1,8-cineole (3.04\%) and $\alpha$-pinene (1.04\%) might explain the antimicrobial properties against Gram positive bacteria and yeast, owing to their capacity to destroy the cellular integrity of bacteria and to inhibit the respiratory activity in yeast mitochondria. ${ }^{43,44}$ On the other hand, OMSO was less effective against Gram negative bacteria (IZ around $6.0 \mathrm{~mm}$ ), with Pseudomonas aeruginosa as the most resistant species $\left(\mathrm{IZ}=6.0 \mathrm{~mm}\right.$; $\mathrm{MIC}=12.5 \mathrm{mg} \mathrm{mL}^{-1}$;

Table 6 Effects of OMSO on acetic acid-induced writhing in mice

\begin{tabular}{llll}
\hline Group & $\begin{array}{l}\text { Concentration } \\
\left(\mathrm{g} \mathrm{kg}^{-1}\right)\end{array}$ & $\begin{array}{l}\text { Number of } \\
\text { writhes }^{a}\end{array}$ & $\begin{array}{l}\text { Writhing } \\
\text { inhibition (\%) }\end{array}$ \\
\hline Control & - & $100 \pm 4^{\mathrm{a}}$ & - \\
& 0.5 & $37 \pm 5^{\mathrm{b}}$ & 63 \\
OMSO & 1 & $25 \pm 4^{\mathrm{b}}$ & 75 \\
& 2.5 & $16 \pm 2^{\mathrm{c}}$ & 84 \\
Reference drug (ASL) & 0.2 & $32 \pm 5^{\mathrm{b}}$ & 68
\end{tabular}

${ }^{a}$ Values are expressed as mean \pm SD $(n=6)$. Different letters in this column indicate statistically significant differences $(p<0.05)$ among values according to the Student-Newman-Keuls post hoc test. ${ }^{b}$ ASL: lysine acetylsalicylate.

Table 5 Antibacterial and antifungal activity (MIC, MBC and MFC in $\mathrm{mg} \mathrm{mL}^{-1}$ ) of OMSO

\begin{tabular}{|c|c|c|c|c|c|c|}
\hline \multirow{2}{*}{ Microorganisms } & \multicolumn{3}{|l|}{ OMSO } & \multicolumn{3}{|l|}{ Drug } \\
\hline & $\mathrm{IZ}^{a}$ & $\mathrm{MIC}^{b}$ & $\mathrm{MBC}^{c}$ & $\mathrm{IZ}^{a}$ & $\mathrm{MIC}^{b}$ & $\mathrm{MBC}^{c} / \mathrm{MFC}^{d}$ \\
\hline Bacterial strains & & & & Ampicillin & & \\
\hline Staphylococcus aureus ATCC 25923 & $10.3 \pm 0.5$ & 0.781 & 3.12 & $32.5 \pm 0.5$ & 0.078 & 0.625 \\
\hline Listeria monocytogenes ATCC 19115 & $11 \pm 1$ & 0.390 & 1.56 & $12.3 \pm 0.5$ & 0.023 & 0.093 \\
\hline Bacilus aureus ATCC 11778 & $7.0 \pm 0.5$ & 1.56 & 12.5 & $26 \pm 1$ & 0.078 & 0.625 \\
\hline Enterococcus faecalis ATCC 29212 & $8 \pm 1$ & 0.781 & 6.25 & $13.7 \pm 0.5$ & 0.023 & 0.093 \\
\hline Vibrio parahaemolyticus ATCC 17802 & $6.0 \pm 0.5$ & 3.12 & $>25.0$ & $13.3 \pm 0.5$ & 0.011 & 3.00 \\
\hline Escherichia coli ATCC 35218 & $6.0 \pm 0.5$ & 6.25 & $>25.0$ & $11.7 \pm 0.5$ & 0.023 & 3.00 \\
\hline Pseudomonas aeruginosa ATCC 27853 & $6.0 \pm 0.5$ & 12.50 & $>25.0$ & $22.7 \pm 0.5$ & 0.011 & 12.0 \\
\hline Salmonella typhimurium ATCC 1408 & $6.0 \pm 0.5$ & 6.25 & $>25.0$ & $18 \pm 1$ & 0.023 & 0.093 \\
\hline Yeast strains & $\mathrm{IZ}^{a}$ & $\mathrm{MIC}^{b}$ & $\mathrm{MFC}^{d}$ & Amphoteri & & \\
\hline Candida albicans ATCC 2019 & $12.3 \pm 0.5$ & 0.781 & 1.56 & $14.7 \pm 0.5$ & 0.024 & 0.781 \\
\hline Candida krusei ATCC 6258 & $10.3 \pm 0.5$ & 3.12 & 12.5 & $12.0 \pm 0.5$ & 0.097 & 0.195 \\
\hline Candida glabrata ATCC 15126 & $10.3 \pm 0.5$ & 1.56 & 6.25 & $6.0 \pm 0.5$ & 0.39 & 6.25 \\
\hline Candida parapsilosis ATCC 22019 & $11 \pm 1$ & 0.781 & 3.12 & $10.3 \pm 0.5$ & 0.20 & 0.39 \\
\hline
\end{tabular}

${ }^{a}$ IZ: inhibition zone $(\mathrm{mm})$ around discs impregnated with OMSO (10 mg per disk), Ampicillin $\left(10 \mathrm{mg} \mathrm{mL}^{-1}\right)$ or Amphotericin B $\left(10 \mathrm{mg}^{-1}\right.$ ) expressed as mean $\pm \mathrm{SD}(n=3) .{ }^{b} \mathrm{MIC}$ : minimal inhibitory concentration $\left(\mathrm{mg} \mathrm{mL}{ }^{-1}\right) .{ }^{c} \mathrm{MBC}$ : minimal bactericidal concentration $\left(\mathrm{mg}^{-1} \mathrm{~mL}^{-1}\right)$. ${ }^{d}$ MFC: minimal fungicidal concentration $\left(\mathrm{mg} \mathrm{mL}^{-1}\right)$. 
Table 7 Effects of OMSO on the rat paw carrageenan induced oedema

\begin{tabular}{|c|c|c|c|c|c|c|c|}
\hline \multirow[b]{2}{*}{ Group } & \multirow[b]{2}{*}{ Dose $\left(\mathrm{g} \mathrm{kg}^{-1}\right)$} & \multicolumn{6}{|c|}{ Mean swelling thickness $\left(10^{-2}\right) \pm \mathrm{SD}^{a}(\% \text { of inhibition })^{b}$} \\
\hline & & $1 \mathrm{~h}$ & $2 \mathrm{~h}$ & $3 \mathrm{~h}$ & $4 \mathrm{~h}$ & $5 \mathrm{~h}$ & $24 \mathrm{~h}$ \\
\hline Control & - & $21 \pm 1^{\mathrm{a}}$ & $31 \pm 2^{\mathrm{a}}$ & $50 \pm 2^{\mathrm{a}}$ & $53 \pm 3^{\mathrm{a}}$ & $55 \pm 2^{\mathrm{a}}$ & $30 \pm 1^{\mathrm{a}}$ \\
\hline OMSO & $\begin{array}{l}0.5 \\
1 \\
2.5\end{array}$ & $\begin{array}{l}17 \pm 1^{\mathrm{a}}(19 \%) \\
15 \pm 1^{\mathrm{b}}(28 \%) \\
10 \pm 3^{\mathrm{b}}(52 \%)\end{array}$ & $\begin{array}{l}21 \pm 1^{\mathrm{b}}(32 \%) \\
15 \pm 1^{\mathrm{c}}(51 \%) \\
12 \pm 1^{\mathrm{c}}(61 \%)\end{array}$ & $\begin{array}{l}21 \pm 1^{\mathrm{b}}(58 \%) \\
18 \pm 1^{\mathrm{c}}(64 \%) \\
15 \pm 1^{\mathrm{c}}(70 \%)\end{array}$ & $\begin{array}{l}21 \pm 1^{\mathrm{b}}(60 \%) \\
15 \pm 1^{\mathrm{c}}(71 \%) \\
10 \pm 1^{\mathrm{d}}(81 \%)\end{array}$ & $\begin{array}{l}24 \pm 1^{\mathrm{b}}(56 \%) \\
19 \pm 1^{\mathrm{c}}(66 \%) \\
12 \pm 1^{\mathrm{d}}(78 \%)\end{array}$ & $\begin{array}{r}12 \pm 1^{\mathrm{c}}(59 \%) \\
9 \pm 1^{\mathrm{d}}(70 \%) \\
6 \pm 1^{\mathrm{e}}(80 \%)\end{array}$ \\
\hline $\mathrm{ASL}^{c}$ & 0.3 & $10 \pm 1^{\mathrm{b}}(5210 \%)$ & $13 \pm 1^{\mathrm{c}}(58 \%)$ & $20 \pm 1^{\mathrm{b}}(60 \%)$ & $18 \pm 1^{\mathrm{b}}(66 \%)$ & $20 \pm 1^{\mathrm{c}}(64 \%)$ & $16 \pm 1^{\mathrm{b}}(47 \%)$ \\
\hline
\end{tabular}

${ }^{a}$ Values are expressed as mean $\pm \mathrm{SD}(n=6$ animals per dose per time point). Different letters in each column indicate statistically significant differences $(p<0.05)$ among values according to the Student-Newman-Keuls post hoc test. ${ }^{b}$ Percent swelling $=\left(\left(V_{\mathrm{f}}-V_{\mathrm{i}}\right) / V_{\mathrm{i}}\right) \times 100$, where $V_{\mathrm{i}}$ is the initial paw volume and $V_{\mathrm{f}}$ is the paw volume after the carrageenan injection. ${ }^{c}$ ASL: lysine acetylsalicylate.

MBC > $25.0 \mathrm{mg} \mathrm{mL} \mathrm{m}^{-1}$ ). When compared to commercial drugs, the antibacterial activity of OMSO was lower than ampicillin (despite the similarity of the IZ in the case of L. monocytogenes). However, the antifungal activity was very similar (specifically considering IZ) to the one achieved with amphotericin B, which might be an indicator of the potential use of OMSO in related applications.

\section{Animal tests}

Acute toxicity. Swiss albinos mice were observed for $48 \mathrm{~h}$ and morbidity and/or mortality were recorded. The tested OMSO concentrations did not exhibit any mortality or toxicity symptoms in all groups receiving intraperitoneally doses up to a maximum of $5 \mathrm{~g} \mathrm{~kg}^{-1}$ body weight, indicating its potential safe use below that concentration. The non-toxic nature of OMSO is comparable to that observed for $O$. ficus indica seed oil. ${ }^{45}$

Analgesic activity. The analgesic effect of OMSO, assessed as the percent reduction of the number of writhes induced with acetic acid, was shown to be proportional to the administered concentration (Table 6). In fact, the highest percent reduction (84\%) was achieved with the highest assayed concentration $\left(2.5 \mathrm{~g} \mathrm{~kg}^{-1}\right)$, which is still below the maximum value showing non-toxic effects (see the previous section). Still, all assayed OMSO concentrations induced a significantly lower number of writhes than the corresponding control $(p<0.05)$. The excellent analgesic activity of OMSO, which might be related to its composition in unsaponifiable compounds, ${ }^{46}$ is also validated by its similarity to the one (68\% at $\left.0.2 \mathrm{~g} \mathrm{~kg}^{-1}\right)$ achieved with the commercial standard (ASL). Furthermore, it should be highlighted that the applied methodology allows investigating both central and peripheral analgesic activities. ${ }^{46}$

Anti-inflammatory activity. As reported in Table 7, OMSO decreased the carrageenan induced oedema rates in the subplantar region of the hind paw in a dose-related manner (in all periods of time), reaching the maximum inhibition percentages at $2.5 \mathrm{~g} \mathrm{~kg}^{-1}$ (81\%). The level of anti-inflammatory activity was remarkable, being comparable to the one obtained with the positive control (lysine acetylsalicylate), despite the differences in the assayed concentrations. The maximum antiinflammatory effect was achieved after 4 hours for all the doses, independent of the administered dose. In general, there was a gradual increase in oedema paw volume in the control group up to $5 \mathrm{~h}$ after carrageenan injection, further showing a marked decrease from 5 to $24 \mathrm{~h}$. The observed anti-inflammatory activity might be associated with an inhibitory effect over the release of pro-inflammatory mediators of acute inflammation, such as histamine and prostaglandins. In fact, some of the compounds (e.g., $\gamma$-tocopherol) present in the unsaponifable fraction of OMSO may exert anti-inflammatory effects by inhibiting the synthesis, release and/or the action of inflammatory mediators like histamine, serotonin and different prostaglandins. $^{47}$

\section{Conclusions}

In general, OMSO showed good characteristics to be considered as a new edible oil, as exemplified by its low acidity value $(1.15 \%)$, stability to oxidation (considering its high peroxide value and low $K_{232}$ and $K_{270}$ values), high content of unsaturated fatty acids (as indicated by the iodine value) and the quantity of saponifiable matter.

OMSO showed high antioxidant activity (especially regarding lipid peroxidation inhibition), which might be related to its high contents of $\beta$-carotene and $\gamma$-tocopherol. The high levels of tocopherol could also be related to its $\alpha$-glucosidase inhibitory activity, which should be considered as a promising result, since this natural product is not expected to induce the adverse effects typically caused by other blood glucose controlling agents.

In addition, this oil exerted a cytotoxic effect on the tested human tumour cell lines (except MCF7), among which HCT15 (colon carcinoma) was the most susceptible. Nevertheless, it did not show toxicity against the non-tumour cell line PLP2 (up to $400 \mu \mathrm{g} \mathrm{mL} \mathrm{m}^{-1}$ ).

Concerning the antimicrobial activity, which could be related to its volatiles, OMSO was more effective against Gram positive and yeast strains, showing very positive results, even when compared with commercial drugs (ampicillin and amphotericin B).

The detected bioactivity became particularly interesting after verifying that OMSO did not exert acute toxicity in animal testing. Furthermore, this natural oil presented high analgesic 
and anti-inflammatory properties, especially when tested at $2.5 \mathrm{mg}$ per $\mathrm{kg}$ bw, a concentration below the one $(5 \mathrm{mg}$ per $\mathrm{kg}$ bw) validated as having no toxic effects.

Overall, the present findings suggest possible applications (e.g., nutraceutical, pharmacological or cosmetic) of OMSO, an otherwise undervalued by-product, which might yield important economic benefits.

\section{Competing interests}

The authors declare no competing financial interest.

\section{Acknowledgements}

The authors are grateful to Fundação para a Ciência e a Tecnologia (FCT, Portugal) for financial support to CIMO (strategic project PEst-OE/AGR/UI0690/2011) and J.C.M. Barreira and Ricardo C. Calhelha contracts.

\section{References}

1 Y. Shukla and R. Singh, Ann. N. Y. Acad. Sci., 2011, 1215, 1-8.

2 S. Samah, E. Ventura-Zapata and E. Valadez-Moctezuma, Biochem. Syst. Ecol., 2015, 58, 187-194.

3 P. Morales, E. Ramírez-Moreno, M. de C. Sanchez-Mata, A. M. Carvalho and I. C. F. R. Ferreira, Food Res. Int., 2012, 46, 279-285.

4 N. Chougui, A. Tamendjari, W. Hamidj, S. Hallal, A. Barras, T. Richard and R. Larbat, Food Chem., 2013, 139, 796803.

5 H. Chahdoura, J. C. M. Barreira, L. Barros, C. SantosBuelga, I. C. F. R. Ferreira and L. Achour, Ind. Crops Prod., 2015, 65, 383-389.

6 H. Chahdoura, P. Morales, J. C. M. Barreira, L. Barros, V. Fernández-Ruiz, I. C. F. R. Ferreira and L. Achour, LWT-Food Sci. Technol., 2015, 64, 446-451.

7 F. Naselli, L. Tesoriere, F. Caradonna, D. Bellavia, A. Attanzio, C. Gentile and M. A. Livrea, Anti-proliferative and pro-apoptotic activity of whole extract and isolated indicaxanthin from Opuntia ficus-indica associated with reactivation of the onco-suppressor p16INK4a gene in human colorectal carcinoma (Caco-2) cells, 2014, vol. 450.

8 A. Smida, S. Ncibi, J. Taleb, A. Ben Saad, S. Ncib and L. Zourgui, Biomed. Pharmacother., 2017, 88, 844-851.

9 I. Ammar, M. Ennouri, B. Khemakhem, T. Yangui and H. Attia, Ind. Crops Prod., 2012, 37, 34-40.

10 A. Cardador-Martinez, C. Jimenez-Martinez and G. Sandoval, Cienc. Tecnol. Aliment., 2011, 31, 782-788.

11 F. C. Stintzing, A. Schieber and R. Carle, Eur. Food Res. Technol., 2001, 212, 396-407.

12 A. P. Simopoulos, J. Am. Coll. Nutr., 2002, 21, 495-505.

13 H. Maeda, T. L. Sage, G. Isaac, R. Welti and D. Dellapenna, Plant Cell, 2008, 20, 452-470.
14 A. P. Simopoulos, Biomed. Pharmacother., 2002, 56, 365-379.

15 AOCS, in Determination of cis-, trans-, Saturated, Monounsaturated and Polyunsaturated Fatty Acids in Vegetable or Non-Ruminant Animal Oils and Fats by Capillary GLC (Ce 1h-05), 2009, vol. Ce 1h-05.

$16 \mathrm{M}$. Isabel Minguez-Mosquera, L. Rejano-Navarro, B. Gandul-Rojas, A. H. SanchezGomez and J. GarridoFernandez, J. Am. Oil Chem. Soc., 1991, 68, 332-336.

17 S. Dabbou, C. Lussiana, S. Maatallah, L. Gasco, H. Hajlaoui and G. Flamini, Plant Physiol. Biochem., 2016, 100, 1-11.

18 R. Re, N. Pellegrini, A. Proteggente, A. Pannala, M. Yang and C. Rice-Evans, Free Radical Biol. Med., 1999, 26, 1231-1237.

19 B. E. C. Ziani, R. C. Calhelha, J. C. M. Barreira, L. Barros, M. Hazzit and I. C. F. R. Ferreira, Ind. Crops Prod., 2015, 77, 582-589.

20 Y. Tao, Y. Zhang, Y. Cheng and Y. Wang, Biomed. Chromatogr., 2013, 27, 148-155.

21 V. Vuddhakul, P. Bhoopong, F. Hayeebilan and S. Subhadhirasakul, Food Microbiol., 2007, 24, 413-418.

22 M. Snoussi, E. Noumi, N. Trabelsi, G. Flamini, A. Papetti and V. De Feo, Molecules, 2015, 20, 14402-14424.

23 S. Saha, T. Guria, T. Singha and T. K. Maity, ISRN Pharmacol., 2013, 2013, 789613.

24 C. A. Winter, E. A. Risley and G. W. Nuss, Exp. Biol. Med., 1962, 111, 544-547.

25 A. Boukeloua, A. Belkhiri, Z. Djerrou, L. Bahri, N. Boulebda and Y. Hamdi Pacha, Afr. J. Tradit., Complementary Altern. Med., 2012, 9, 607-611.

26 M. M. Özcan and F. Y. Al Juhaimi, Int. J. Food Sci. Nutr., 2011, 62, 533-536.

27 E. N. Onyeike and G. N. Acheru, Food Chem., 2002, 77, 431437.

28 I. El Mannoubi, S. Barrek, T. Skanji, H. Casabianca and H. Zarrouk, Chem. Nat. Compd., 2009, 45, 616.

29 C. Gertz and S. Klostermann, Eur. J. Lipid Sci. Technol., 2000, 102, 329-336.

30 F. Al-Juhaimi and M. M. Özcan, Environ. Monit. Assess., 2013, 185, 3659-3663.

31 M. D. Salvador, F. Aranda, S. Gómez-Alonso and G. Fregapane, Food Chem., 2001, 74, 267-274.

32 M. Damechki, S. Sotiropoulou and M. Tsimidou, Grasas Aceites, 2001, 52, 207-213.

33 M. F. Ramadan and J. T. Mörsel, Food Chem., 2003, 82, 339-345.

34 B. Matthäus and M. M. Özcan, Sci. Hortic., 2011, 131, 95-98.

35 M. Deiana, A. Rosa, C. F. Cao, F. M. Pirisi, G. Bandino, M. A. Dessi and M. A. Dessì, J. Agric. Food Chem., 2002, 50, 4342-4346.

36 S. Vichi, A. I. Castellote, L. Pizzale, L. S. Conte, S. Buxaderas and E. López-Tamames, J. Chromatogr., A, 2003, 983, 19-33.

37 M. Moss and L. Oliver, Ther. Adv. Psychopharmacol., 2012, 2, 103-113.

38 H. Chahdoura, J. C. M. Barreira, L. Barros, C. SantosBuelga, I. C. F. R. Ferreira and L. Achour, Food Funct., 2014, 5, 2129-2136. 
39 D. Li, T. Saldeen, F. Romeo and J. L. Mehta, J. Cardiovasc. Pharmacol. Ther., 1999, 4, 219-226.

40 A. Van de Laar Floris, L. B. J. Lucassen Peter, P. Akkermans Reinier, H. Van de Lisdonk Eloy and J. C. De Grauw Wim, Cochrane Database Syst. Rev., 2006, 4, CD005061.

41 M. Y. Ali, S. Jannat, H. A. Jung, H. O. Jeong, H. Y. Chung and J. S. Choi, Chem.-Biol. Interact., 2016, 252, 93101.

42 J. H. Y. Wu, N. C. Ward, A. P. Indrawan, C.-A. Almeida, J. M. Hodgson, J. M. Proudfoot, I. B. Puddey and K. D. Croft, Clin. Chem., 2007, 53, 511-519.
43 E. Mancini, F. Senatore, D. Del Monte, L. De Martino, D. Grulova, M. Scognamiglio, M. Snoussi and V. De Feo, Molecules, 2015, 20, 12016-12028.

44 M. Mahboubi and N. Kazempour, Indian J. Pharm. Sci., 2009, 71, 343-347.

45 A. Berraaouan, A. Ziyyat, H. Mekhfi, A. Legssyer, M. Sindic, M. Aziz and M. Bnouham, Pharm. Biol., 2014, 52, 1286-1290.

46 M. Fezai, L. Senovilla, M. Jemaà, M. Ben-Attia and M. Ben-Attia, J. Lipids, 2013, 2013, 1-7.

47 A. S. Shah and K. R. Alagawadi, J. Ethnopharmacol., 2011, 137, 1504-1509. 